Małgorzata Siwińska

\title{
ECOLOGICAL TOURISM AND LOCAL DEVELOPMENT IN COSTA RICA
}

\section{INTRODUCTION}

Costa Rica has gained worldwide recognition as a country that is actively promoting environmental protection, particularly in relation to forests and biodiversity. It is necessary to mention that the national territory of only 51000 square kilometres is inhabited by at least half a million of species almost 4 per cent of the world's terrestrial living species (Utting, 1998). Its high biodiversity (both plants and animals), variety of landscapes and local cultures constitute best conditions for development of ecological tourism. Therefore, great efforts has been made to direct tourist offer towards sustainable development, which aims at stimulating economic and social benefits on the basis of protection and conservation of the ecosystems and natural resources.

The paper intends to show the influence of ecological tourism on the activity of local communities, on the basis of the literature as well as my experiences gained during the visit in Costa Rica in 1999.

\section{TOURISM AND PROTECTED AREAS IN COSTA RICA.}

The pro-ecological policy, like promotion of conservation of the nature and ecological tourism, conducted by the government of Costa Rica led to rapid increase in foreign tourism. According to National Tourism Board (ICT) the number of tourists rose from 435000 in 1990 to over 940000 by 1998. For instance in 1998 a $16 \%$ increase of number of tourists was noted as compared with the previous year (Morera, 2001). In 1997 Costa Rica was principal tourist destination in Central America and tourism became its leading source of foreign exchange (WTO), after coffee, exceeding traditional exports like banana (Morera, 2001).

Before the tourist boom, National Parks Service was created in $1970-$ the first system of public and private protected areas, which now covers over $25 \%$ of the country. Almost all of the Costa Rica's natural habitats are represented in 147 protected areas. These areas are divided into nine 
categories of management such as: national park (33), biological reserve (8), national monument (1), forest reserve (11), protected zone (31), wildlife refuge (38), wetland (14), absolute natural reserve (2) and other area (9) (table 1).

Table 1.

Protected areas in relation to national territory

\begin{tabular}{|l|c|c|}
\hline \multicolumn{1}{|c|}{ Category of management } & $\begin{array}{c}\text { Number } \\
\text { of protected areas }\end{array}$ & $\begin{array}{c}\text { Percent in relation } \\
\text { to national territory }\end{array}$ \\
\hline National Park & 33 & 12.26 \\
\hline Biological Reserve & 8 & 0.42 \\
\hline National Monument & 1 & -- \\
\hline Forest Reserve & 11 & 4.26 \\
\hline Protected Zone & 31 & 3.07 \\
\hline Wildlife Refuge & 38 & 3.42 \\
\hline Wetland (with mangroves) & 14 & 1.81 \\
\hline Absolute Natural Reserve & 2 & 0.03 \\
\hline Other area (experiment station) & 9 & 0.31 \\
\hline Total & $\mathbf{1 4 7}$ & $\mathbf{2 5 . 5 8}$ \\
\hline
\end{tabular}

Source: Ministerio del Ambiente y Energía — Sistema Nacional de Areas de Conservación, 1999.

According to Ministry of Environment and Energy (MINAE) between 55 and 70 percent of the international tourists visit Costa Rica every year for its national parks. This fact clearly demonstrates how important is the role of the protected areas in tourism and socio-economic development.

It is necessary to mention that during the decades of the seventies and eighties many of these areas where called pejoratively as "paper parks", because their protected area status existed only in legal documents and not on the ground. However during the last decade a series of institutional reforms and improved funding have facilitated the task of administering and regulating some national parks and reserves (Siwińska, 2000).

\section{ECOLOGICAL TOURISM AND LOCAL COMMUNITIES}

According to IUCN (International Union for Conservation of Nature) the ecological tourism is defined as "environmentally responsible travel and visitation to relatively undisturbed or uncontaminated natural areas with the specific objective of studying, admiring, and enjoying the natural attractions (scenery and its wild plants and animals), as well as any existing cultural manifestations (both past and present) found in these areas through the process that promotes conservation, has low environmental and cultural impact, and provides active and socio-economic beneficially involvement of 
local populations" (Ceballos-Lascuráin, 1998). So, ecological tourism, if managed well, can be a sustainable and relatively simple alternative. It gives opportunities of employment and income to local communities and needed foreign exchange to national government, while allowing a continued existence of the natural resource base. In fact, it cannot survive unless the resource on which it is based is protected. It can empower local communities, giving them a sense of pride in their natural resources and control over their communities' development. Summing up, it has the potential to maximize economic benefits and minimize environmental costs.

Due to the fact that farming, forestry, mining and hunting are excluded from most protected areas in Costa Rica, local communities must replace income from these activities by tourism - generated income. Usually they find employment through small - scale tourism enterprises. This is in case of Cahuita National Park which is located on Costa Rica's southern Caribbean coast, close to Panama border. In the district, where almost 4000 people live (including the village of Cahuita and surrounding settlements), there are about 70 businesses, ranging from tour agencies and hotels to restaurants and bakeries (Weitzner, Fonesca Borrás, 2001). Therefore, tourist services are the main occupation of the local population. Some fishers from Cahuita sell their catch - primarily lobster and variety of fish — to local restaurants and families, obtaining benefits from tourism indirectly. Another small number of Cahuitans and people from neighbouring communities supplement their income by offering some sport activities to the tourists - fishing and snorkelling outings, but still engage in traditional resource-based activities (Weitzner, Fonesca Borrás, 2001).

Some of the inhabitants see the conversion of the source of livelihood from agriculture (cocoa crops) to a tourism-dependent one as a cultural loss. They link the cultural degradation to growing social problems in the village, such as drugs and alcoholism. This is why a number of community organizations have cropped up to help defy these social problems, and other organizations are working to strengthen Cahuitans' cultural identity and cohesion (Weitzner, Fonesca Borrás, 2001).

Tourism to Cahuita National Park has brought many changes to local community. One of the most important is the involvement of habitants in the management of protected area and creation of new possibility of additional economic benefits.

Another example of ecotourism-based economy is illustrated by Bahia Drake region, which comprises five small communities located on the Osa Peninsula's Pacific coast in southern Costa Rica. I will focus only upon Agujitas, the tourism center, and Los Planes, its closest neighbor. Agujitas, located on the Bahia itself, has about 65 households, while the more remote Los Planes, located in the hills behind Agujitas, has almost 40 homes. The Bahia Drake region was virtually unknown until the establishment of Corcovado National Park in 1975. The park was later expanded in 1980 and different kinds of tourist services and infrastructure have developed. In Agujitas 
for example there are ten small lodges, four of which are higher-end establishments with fixed packages, catering primarily to foreign, higher-paying clientele. Three of the four are foreign-owned. (Stem, 2001). Usually, these lodges offer some English courses to their employees. Those villagers who are not working directly for a hotel are involved in or benefit economically from tourism in some form. Some rent horses to local hotels, while others sell fruits, vegetables, or meat to the hotels. Others provide boat transportation or run a small general store visited by tourists. Tourism as a source of employment has also played a key role in helping younger generations to contribute to their family's income and, in many cases, support ageing parents unable to work. Despite the area's economic growth, Bahia Drake region still remains isolated from basic national infrastructure. Consequently, the communities have become self-sufficient "islands", with hotels and families supplying their own electricity through diesel-powered generators, disposing of their garbage independently, and meeting water and sanitation needs through individual supply and septic systems. Many houses, especially those involved in tourism, have radios for communication with other tourism operators (Stem, 2001).

The increase of tourism to Corcovado National Park has become an economically viable alternative to forest dependence. Unemployment is not currently an issue for most of Bahia Drake communities. In Agujitas approximately $90 \%$ of residents depend upon tourism, directly or indirectly. Los Planes, on the other hand, has about $50-60 \%$ of the population involved in tourism (Stem, 2001).

In sharp contrast to communities from Bahia Drake region, it is interesting to mention about La Gamba community. The village is located on the mainland close to Golfo Dulce in southern Costa Rica and adjoins Piedras Blancas National Park and the Golfito Wildlife Refuge (former parts of Corcovado National Park - Esquinas Sector). La Gamba is small rural community of just over 100 households (Stem, 2001). The expansion of Corcovado National Park affected villagers living in or near the park. Most were there long before the declaration of the park and have subsequently found themselves beholden to harsh restrictions on resource use. The government has paid off some of those people, but many still await reimbursement for lost land and opportunities. This is why the case of La Gamba is one of the most severe. The mainstay of that community is agriculture and livestock production. Many support themselves or supplement their income through day laborers jobs on others' farms. Some of the Gambenos work in the duty free zone in Golfito, established by the Costa Rican government to boost the economy of the southern region (Stem, 2001). The only other significant source of employment is Esquinas Rainforest Lodge. Built in 1994 with the support of funding from the Austrian government, the ecotourism lodge was to provide an alternative income source to La Gamba. Profits from the hotel theoretically support local social and development initiatives. The Esquinas Rainforest Lodge, however has fallen short of meeting most of its lofty objectives (Stem, 2001). Initial interactions with the community were fraught with misunderstandings and 
resultant mistrust. Originally, the Austrian government had planned to train Gambenos and eventually turn over management and ownership to the community. When this did not occur within the first few months of operation, residents felt deceived. Some even made an attempt to take over the hotel. Given the reaction of the community to the hotel, the Austrian government determined it was best for the hotel to remain in external hands but for all the personnel, with the exception of the managerial staff, to come from La Gamba.

In summary, in La Gamba, tourism occupies a very small place in the economy and, consequently, has not really offered a feasible alternative to the community as a whole. The Esquinas Rainforest Lodge provides a stable income source and benefits to approximately 15 families. However, several hotel employees supplement their income through agriculture and livestock (Stem, 2001). Some habitants try to benefit from tourism through indirect income related to services or products sold to the lodge or tourists (horse rent, fruit sale etc.). Also, Piedras Blancas National Park is a potential economic opportunity, albeit for just a few park workers. The case of La Gamba illustrates how Costa Ricans, once primarily independent family farmers, now find themselves increasingly relegated to providing low - waged services to foreign tourists while generating profits for foreign entrepreneur.

As in La Gamba, but on a large scale, the community of Tortuguero depends on supply and demand controlled by "external" tourism investors. In addition, among Costa Rica's national parks, Tortuguero provides one of the best examples of a park created in a populated area where the local economy previously depended on the commercial exploitation of natural resources now protected by the park. The small village of Tortuguero lies on the northeastern Caribbean coast of Costa Rica and is completely surrounded by protected areas: a national park to the south, a wildlife refuge to the north, and a protected zone corridor linking the refuge and the park. This region is well known as a tourist destination, mainly due to the presence of the green turtle and the richness of the humid tropical forest. Visitors who were coming to Tortuguero (first of all Costa Ricans) before the tourist boom (1985) stayed in rustic cabañas and ate in comedores owned by villagers (Place, 1998). That provided to economic benefits for local community. The situation changed by the mid-1980s, when state government decided to promote foreign tourism under pressure from various international institutions. The number of foreign visitors began to increase considerably in 1990. "In 1982, only 355 foreigners visited the park (about 42 percent of total visitors), while 488 Costa Ricans visited. In 1992, the park received 19,691 foreign visitors and only 50 Costa Ricans!" (Place, 1998). The outside investors moved in following up possibilities to gain, reducing the opportunity for village entrepreneurs to become involved in the tourism business. The villagers have lost a chance to accumulate their own capital to invest in tourist facilities and services. Thus, the income generated by the 'non-consumptive' use of local resources flows to the outsiders who bring the tourists to Tortuguero and provide their own 
luxury accommodation and other services located outside the village. In that way, local inhabitants lost control over their economic development process. Some of them even had left community. Those who stayed work as waitresses, bartenders or kitchen assistants in outside enterprises or try to receive income from small-scale budget tourism. Tortuguero's experience indicates that preserving large expanses of natural or near natural ecosystems may not necessarily promote rural development, or even permit the support of the existing rural populace, if economic alternatives to resources extraction are not provided (Place, 1991).

\section{CONCLUSIONS}

The study clearly stresses the importance of including local people in the planning, development, and management of ecological tourism. Many of the protected areas are surrounded by native populations who are dependent on the natural resources of the area for their livelihood. In order to stem the growing pressure from development activities and conserve the natural resources, the local communities must be offered viable alternatives to use the resources in sustainable ways. Ecological tourism is one such option.

In Costa Rica the process of involving native populations in ecological tourism portrays a very complex picture. The case studies illustrate how scale influences the distribution of benefits and impacts associated with tourism. At a large scale, ecological tourism may offer significant economic benefits and discourage the conversion of forest to agricultural and pastoral land. On the other hand, negative impacts, such as increased social and cultural disintegration and rising costs of living may also accompany ecological tourism, especially when it occupies a major role in the local economy.

The paper also presented the change in government policy in relation to local communities (case of Cahuita). In the early days of the creation of a system of protected areas in Costa Rica, locals were not included in planning, nor were they allowed to use their natural resources. However, government agencies and conservation organizations have begun to turn toward a more localized approach (the creation of Conservation Areas), with an emphasis on sustainable development as a solution.

The challenges for the future of the protected areas in Costa Rica are focused on increasing the incorporation of the local community, mitigating the negative effects of ecological tourism, maintaining a low scale of tourism and increasing the conservation of the adjacent areas.

\section{REFERENCES}

Ceballos-Lascuráin H., 1998, Ecoturismo. Naturaleza y Desarrollo Sostenible, Editorial Diana, México.

Ministerio del Ambiente y Energía (MINAE), 1999, Tablas Estadísticas, San José, Costa Rica. 
Morera Beita C.M., 2001, El desarrollo turístico de Costa Rica: un modelo en conformación, Revista GeoNotas, Departamento de Geografía, Universidad Estadual de Maringá, vol. 5,2 .

Place S., 1991, Nature tourism and rural development in Tortuguero, [in:] Annals of Tourism Research, vol. 18, pp. 186-201.

Place S., 1998, How sustainable is ecotourism in Costa Rica?, [in:] Hall C.M., Lew A.A., Sustainable tourism: a geographical perspective, Longman, pp. 107-118.

Siwińska M., 2000, Turystyka na obszarach chronionych w Meksyku i Kostaryce - stan obecny, [in:] Afryka, Azja, Ameryka Eacinska, vol. 77, Warszawa, pp. 15-21.

$\mathrm{S}$ te $\mathrm{m}$ C.J., 2001, The role of local development in protected area management: a comparative case study of eco-tourism in Costa Rica, Cornell University, Ithaca, NY.

Utting P., 1998, Biodiversity protection and action research in Costa Rica, United Nations Research Institute for Social Development (UNRISD), News Number 19, Geneva, Switzerland.

Weitzner V., Fonesca Borrás M., 2001, Cahuita, Limón, Costa Rica: From conflict to collaboration, [in:] Cultivating Peace, Chapter 6. Part 2. Coastal Areas, International Development Research Center (IDRC), Canada. 